\title{
A cross-sectional study of US rural adults' consumption of fruits and vegetables: do they consume at least five servings daily?
}

\author{
M. Nawal Lutfiyya ${ }^{1 *+}$, Linda F. Chang ${ }^{2+}$ and Martin S. Lipsky ${ }^{2+}$
}

\begin{abstract}
Background: Rural residents are increasingly identified as being at greater risk for health disparities. These inequities may be related to health behaviors such as adequate fruits and vegetable consumption. There is little national-level population-based research about the prevalence of fruit and vegetable consumption by US rural population adults. The objective of this study was to examine the prevalence differences between US rural and non-rural adults in consuming at least five daily servings of combined fruits and vegetables.

Methods: Cross-sectional analysis of weighted 2009 Behavioral Risk Factor Surveillance Survey (BRFSS) data using bivariate and multivariate techniques. 52,259,789 US adults were identified as consuming at least five daily servings of fruits and vegetables of which 8,983,840 were identified as living in rural locales.

Results: Bivariate analysis revealed that in comparison to non-rural US adults, rural adults were less likely to consume five or more daily servings of fruits and vegetables $(\mathrm{OR}=1.161,95 \% \mathrm{Cl} 1.160-1.162)$. Logistic regression analysis revealed that US rural adults consuming at least five daily servings of fruits and vegetables were more likely to be female, non-Caucasian, married or living with a partner, living in a household without children, living in a household whose annual income was $>\$ 35,000$, and getting at least moderate physical activity. They were also more likely to have a BMI of $<30$, have a personal physician, have had a routine medical exam in the past 12 months, self-defined their health as good to excellent and to have deferred medical care because of cost. When comparing the prevalence differences between rural and non-rural US adults within a state, 37 States had a lower prevalence of rural adults consuming at least five daily servings of fruits and vegetables and 11 States a higher prevalence of the same.

Conclusions: This enhanced understanding of fruit and vegetable consumption should prove useful to those seeking to lessen the disparity or inequity between rural and non-rural adults. Additionally, those responsible for health-related planning could benefit from the knowledge of how their state ranks in comparison to others vis-à-vis the consumption of fruits and vegetables by rural adults - a population increasingly being identified as one at risk for health disparities.
\end{abstract}

Keywords: Rural health, Fruit and vegetable consumption, Adult nutrition, BRFSS

\footnotetext{
* Correspondence: mlutfiyya@eirh.org

${ }^{\dagger}$ Equal contributors

${ }^{1}$ Essentia Institute of Rural Health, Division of Research, 502 East 2nd Street,

Duluth, MN55805, USA

Full list of author information is available at the end of the article
} 


\section{Background}

Similar to the US Healthy People 2000 (HP 2000) and HP 2010 objectives, Healthy People 2020 (HP2020) [1] contains nutrition related objectives that recommend Americans increase their consumption of both fruits and vegetables [2]. The HP 2020 objectives for fruit and vegetable consumption echo the 2010 Dietary Guidelines for Americans that recommend an increase in vegetable and fruit intake for all Americans aged 2 years and older [2]. Furthermore, the newly released guidelines emphasize the importance of consuming a variety of vegetables (i.e. dark-green, red, orange vegetables) and beans and peas [2]. Increasing the consumption of fruits and vegetables is deemed an important public health issue since adequate fruit and vegetable consumption may reduce the risk for several major causes of morbidity and mortality in the U.S. including type 2 diabetes [3], heart disease [4,5], stroke [6] and obesity [7]. Moreover, research also suggests that diets rich in fruits and vegetables are associated with a lower incidence of several cancers [8,9], suggesting that dietary choice is also an important cancer prevention measure [10-12].

In addition to reducing the risk of developing many chronic diseases, there is an increasing and compelling body of clinical evidence supporting the benefit of diet and physical activity in not only health maintenance and disease prevention but also for disease treatment, a process referred to as Medical Nutrition Therapy (MNT) [13]. MNT is an essential component in the management and treatment of conditions such as type 2 diabetes, heart disease, hyperlipidemia, stroke and obesity [14-16]. Several widely disseminated clinical practice guidelines advise eating diets high in whole foods such as fruit, vegetables, and whole grains along with limiting animal protein and avoiding high energy low nutrient foods as an important component of disease management.

Another key HP2020 objective is to identify and track segments of the US population experiencing health inequities with the goal of eliminating disparities. Individuals living in rural settings are one population increasingly being identified as at risk for health disparities [1,17-19]. Health inequities or disparities are differences in health between societal strata or groups that are not only avoidable but that are also unnecessary, unfair and unjust [20]. Rural populations in the US experience a disproportionate burden of a number of chronic conditions and many of the major public health problems in rural areas such as obesity, diabetes and tobacco use require or at the very least call for population-level prevention-based interventions.

Hartley [17] urges researchers who have undertaken the examination of the health of rural Americans to explore why rural residency including culture, community and environment, reinforce negative health behaviors. Other researchers [19] aver that examining how and if rural residency affects health behaviors are equally important and that focusing on such may identify rural residency as a fundamental social cause [21] of health inequities.

While researchers have identified differences in fruit and vegetable intake related to race and ethnicity [22$24]$, age $[25,26]$, socioeconomic factors $[22,27,28]$ and sex $[25,29]$, there is little population-based, national level research examining the consumption of fruits and vegetables by rural populations in the United States. Those studies we found investigating the fruit and vegetable intake of rural populations were limited because they either focused on regional or narrowly defined US populations (e.g., only Hispanic and African American groups or older rural adults) or rural settings outside the US [30-32]

Ultimately focusing on US adults living in rural areas acknowledges the importance of place in social epidemiology and public health concerns [33]. Specifically, when assessing health status, health service utilization, health service deficits, adequacy of health care, and health related behaviors-place or geography matters. It has long been held that the places where people live, work and play either protect and/or promote their health and contribute to the health risks they experience [34]. Previous research has indicated that rural residency is an independent risk factor for obesity [35,36], diabetes $[37,38]$, and cardiovascular disease [37] suggesting that dietary habits such as the consumption of fruits and vegetables by rural individuals may differ from their non-rural counterparts.

This study examined the prevalence differences between US rural and non-rural adults in the consumption of at least five daily servings of combined fruits and vegetables. In addition, this study explored what characteristics if any were associated with rural adults consuming five fruits and/or vegetable servings daily. Finally, this study examined by State the prevalence differences between rural and non-rural adult consumption of at least five daily servings of fruits and vegetables.

\section{Methods}

\section{Data source}

Data from the 2009 Behavioral Risk Factor Surveillance Survey (BRFSS), were examined to determine if there were disparities and/or differences between rural and non-rural adults in regard to the daily consumption of at least five servings of combined fruits and vegetables. BRFSS is a cross-sectional, random digit telephone survey that is a collaborative project of the Centers for Disease Control and Prevention (CDC) and all US states and territories. The survey measures several behavioral risk factors in the adult population aged 18 years and older. Its objective is to collect uniform, state-specific 
data on preventive health practices and risk behaviors linked to chronic diseases, injuries and preventable infectious diseases in the non-institutionalized adult US population.

In this survey, data are collected from a random sample of adults (one per household). All BRFSS data are self-reported responses to mostly forced-choice questions. No additional data are generated to corroborate or substantiate the self-reported responses. As recommended by the $\mathrm{CDC}$, all analyses were performed on weighted data. The weighting provides a stratified representation of the US adult non-institutionalized population that conforms to census data. A more detailed description of the sampling methodology of BRFSS is available elsewhere [39].

\section{Defining rurality}

While there are multiple ways of defining rural for both research as well as policy purposes [40-44], deciding on the specific definition of rural to apply or adopt depends on the purpose of the study, the data used in the analyses, and the appropriate and available taxonomy [42]. Ultimately, there is no perfect definition of rural [42]. In the analyses conducted here, the Metropolitan Statistical Area (MSA) variable included in BRFSS was used to define place of residence as either rural or non-rural. This was the only variable available in the dataset that could be used to define rural or geographical place of residency. As such rural residents were defined as persons living either within an MSA that had no city center or outside an MSA. Non-rural residents included all respondents living in a city center of an MSA, outside the city center of an MSA but inside the county containing the city center, or inside a suburban county of the MSA. The MSA taxonomy was developed by the US Office of Management and Budget and is used by the US Census Bureau and other government agencies for statistical and data analysis purposes [40].

\section{Dependent variable}

The dependent variable for this analysis was consumption of at least 5 daily servings of combined fruits and vegetables. This was a calculated variable derived from survey participant responses to several questions asked by the interviewer administering the survey (see Table 1). Combined fruits and vegetables was chosen as the measure because in the US, fruits such as avocados, tomatoes, corn, peppers, eggplant, squash, and green beans are often misclassified as vegetables when they are in fact fruit. By combining fruits and vegetables we overcome these common misclassifications. Using the measure of a combined five or more servings of fruits and vegetables is consistent with the measurement of fruit and vegetable consumption used in some earlier research $[7,45]$. Furthermore, low fruit and vegetable consumption has been defined by the World Health Organization panel on diet, nutrition, and prevention of chronic diseases as consuming fewer than five servings of fruits and/or vegetables daily [45].

\section{Covariates}

Additionally, a number of covariates were included in the analyses. The mix of covariates chosen for inclusion in the analyses included demographic variables associated with social determinants of health, health services variables associated with receipt of or seeking health care, and health status/health condition variables. The demographic covariates were sex, race and ethnicity, age, education, marital status, children in household and household income. The health services covariates were health insurance status, having a personal physician, timing of last routine medical check-up, and deferment of medical care because of cost. The health status/health condition covariates were self-defined health status, body mass index (BMI), and physical activity. A number of these covariates were re-coded from their original formulation for use in this analysis. Table 1 summarizes the original survey questions and response categories with the re-coded response categories. Missing data were not included in the data analysis.

Age and number of children in the household were the only continuous variables re-coded as categorical ones. The variables education, marital status, household income, have a personal physician, timing of last routine medical check-up, and self-defined health status all had multiple categories that were collapsed into fewer categories for analysis. Race and ethnicity, BMI categories, and physical activity were all calculated variables derived from the responses to several survey questions (see Table 1 for greater detail).

Race and ethnicity was calculated from participant responses to two separate survey questions-one regarding race and the other regarding Latino/Hispanic ethnicity. Combining the responses to these two questions allowed for the derivation of the race and ethnicity variable used here. All race/ethnicity categories were computed as mutually exclusive entities. For example all respondents coded as Caucasian chose white as their racial classification, likewise black for African American, etc. If a respondent identified themselves as Hispanic, they were classified by that ethnic category regardless of any additional racial classification.

BMI was calculated from two survey questions, the first asking the respondents height in feet and inches and the second their weight in pounds. The BMI formula BMI= weight in pounds $\times 703 /$ height in inches ${ }^{2}$ was then used to calculate BMI and code the resultant number into one of three categories: $\mathrm{BMI}<25$ (neither overweight nor obese), BMI $>25-<30$ (overweight), and BMI $>30$ (obese). 
Table 1 Original Survey Question and Response Categories with Re-Coded Response Categories 2009 BRFSS Data

\begin{tabular}{|c|c|c|c|c|}
\hline Analysis Variable & Survey Question & Original Response Categories & & Re-coded Response Categories \\
\hline \multirow[t]{3}{*}{ Fruit and Vegetable Consumption } & $\begin{array}{l}\text { Not counting juice, how } \\
\text { often do you eat fruit? }\end{array}$ & \multirow{3}{*}{$\begin{array}{l}\text { Calculated variable for } \\
\text { consumed five or more } \\
\text { servings of fruits or } \\
\text { vegetables per day derived } \\
\text {-from the servings per day } \\
\text { variables. }\end{array}$} & $\begin{array}{l}\text { Respondents that reported they } \\
\text { never consumed fruits and } \\
\text { vegetables or consumed less } \\
\text { than } 5 \text { servings per day }\end{array}$ & less than 5 servings per day \\
\hline & $\begin{array}{l}\text { How often do you eat } \\
\text { green salad? }\end{array}$ & & $\begin{array}{l}\text { Respondents that reported they } \\
\text { consumed } 5 \text { or more servings of } \\
\text { fruits and vegetables per day }\end{array}$ & $\begin{array}{l}5 \text { or more servings of fruits } \\
\text { and vegetables per day }\end{array}$ \\
\hline & $\begin{array}{l}\text { Not counting carrots, } \\
\text { potatoes, or salad, how } \\
\text { many servings of vegetables } \\
\text { do you usually eat? } \\
\text { (Example: A serving of } \\
\text { vegetables at both lunch } \\
\text { and dinner would be } \\
\text { two servings.) }\end{array}$ & & $\begin{array}{l}\text { Respondents who reported they } \\
\text { didn't know the servings } \\
\text { consumed per day, those who } \\
\text { refused to answer, and those } \\
\text { with missing responses }\end{array}$ & Missing \\
\hline \multirow[t]{2}{*}{ Sex } & \multirow[t]{2}{*}{ Indicate sex of respondent. } & Male & & Male \\
\hline & & Female & & Female \\
\hline \multirow[t]{12}{*}{ Race and Ethnicity } & \multirow{9}{*}{$\begin{array}{l}\text { Which one of these groups } \\
\text { would you say best } \\
\text { represents your race? }\end{array}$} & \multicolumn{3}{|c|}{ Race responses were combined with Hispanic variable to create the second column categories } \\
\hline & & White & White, non-Hispanic & Caucasian \\
\hline & & Black or African American & Black non-Hispanic & African American \\
\hline & & Asian & Asian non-Hispanic & \multirow[t]{5}{*}{ Other/multiracial } \\
\hline & & Native Hawaiian or Other Pacific Islander & $\begin{array}{l}\text { Native Hawaiian or Other Pacific } \\
\text { Islander non-Hispanic }\end{array}$ & \\
\hline & & American Indian, Alaska Native & $\begin{array}{l}\text { American Indian, Alaska Native } \\
\text { non-Hispanic }\end{array}$ & \\
\hline & & Other & Other non-Hispanic & \\
\hline & & Multiracial but preferred race not asked & Multiracial non-Hispanic & \\
\hline & & Don't know/Not sure, Refused & Don't know/Not sure, Refused & Missing \\
\hline & \multirow{3}{*}{$\begin{array}{l}\text { Are you Hispanic or } \\
\text { Latino? }\end{array}$} & Yes & Hispanic & Hispanic \\
\hline & & No & Non-Hispanic & \\
\hline & & Don't know/Not Sure, Refused & Don't know/Not Sure, Refused & Missing \\
\hline \multirow[t]{3}{*}{ Age Range } & \multirow[t]{3}{*}{ What is your age? } & \multirow[t]{3}{*}{ _- age in years } & & 18-34 Years \\
\hline & & & & 35-64 Years \\
\hline & & & & $>=65$ Years \\
\hline \multirow[t]{5}{*}{ Education } & \multirow{5}{*}{$\begin{array}{l}\text { What is the highest grade or } \\
\text { year of school you } \\
\text { completed? }\end{array}$} & Never attended school or only kindergarten & & \multirow[t]{3}{*}{$<$ High School } \\
\hline & & Grades 1 through 8 (Elementary) & & \\
\hline & & \multicolumn{2}{|l|}{ Grades 9 through 11 (Some high school) } & \\
\hline & & \multicolumn{2}{|l|}{ Grade 12 or GED (High school graduate) } & \multirow[t]{2}{*}{ Completed High School } \\
\hline & & \multicolumn{2}{|c|}{ College 1 year to 3 years (Some college or technical school) } & \\
\hline
\end{tabular}


Table 1 Original Survey Question and Response Categories with Re-Coded Response Categories 2009 BRFSS Data (Continued)

\begin{tabular}{|c|c|c|c|c|}
\hline & & \multicolumn{2}{|c|}{ College 4 years or more (College graduate) } & College Graduate \\
\hline & & \multicolumn{2}{|l|}{ Refused, Not asked or Missing } & Missing \\
\hline \multirow[t]{7}{*}{ Marital Status } & \multirow[t]{7}{*}{ Are you: (marital status) } & \multicolumn{2}{|l|}{ Married } & Married or Living with Partner \\
\hline & & \multicolumn{2}{|l|}{ A member of an unmarried couple } & \\
\hline & & \multicolumn{2}{|l|}{ Divorced } & Unmarried and Not Living \\
\hline & & \multicolumn{2}{|l|}{ Widowed } & -With a Partner \\
\hline & & \multicolumn{2}{|l|}{ Separated } & \\
\hline & & \multicolumn{2}{|l|}{ Never married } & \\
\hline & & \multicolumn{2}{|l|}{ Refused, Not asked or Missing } & Missing \\
\hline \multirow[t]{3}{*}{ Children in Household } & \multirow{3}{*}{$\begin{array}{l}\text { How many children less } \\
\text { than } 18 \text { years of age live } \\
\text { in your household? }\end{array}$} & \multicolumn{2}{|c|}{ Number of children: ${ }_{-}=$Number of children } & At Least One Child \\
\hline & & \multicolumn{2}{|c|}{ None } & No Children \\
\hline & & \multicolumn{2}{|l|}{ Refused or Missing } & Missing \\
\hline \multirow[t]{9}{*}{ Household Income } & \multirow{9}{*}{$\begin{array}{l}\text { Is your annual household } \\
\text { income from all sources: }\end{array}$} & \multicolumn{2}{|l|}{ Less than $\$ 10,000$} & $<\$ 35,000$ \\
\hline & & \multicolumn{2}{|c|}{ Less than $\$ 15,000(\$ 10,000$ to less than $\$ 15,000)$} & \\
\hline & & \multicolumn{2}{|c|}{ Less than $\$ 20,000(\$ 15,000$ to less than $\$ 20,000)$} & \\
\hline & & \multicolumn{2}{|c|}{ Less than $\$ 25,000(\$ 20,000$ to less than $\$ 25,000)$} & \\
\hline & & \multicolumn{2}{|c|}{ Less than $\$ 35,000(\$ 25,000$ to less than $\$ 35,000)$} & \\
\hline & & \multicolumn{2}{|c|}{ Less than $\$ 50,000(\$ 35,000$ to less than $\$ 50,000)$} & $>\$ 35,000$ \\
\hline & & \multicolumn{2}{|c|}{ Less than $\$ 75,000(\$ 50,000$ to less than $\$ 75,000)$} & \\
\hline & & \multicolumn{2}{|c|}{$\$ 75,000$ or more } & \\
\hline & & \multicolumn{2}{|c|}{ Don't know/Not sure, Refused and Not asked or Missing } & Missing \\
\hline \multirow[t]{5}{*}{ BMI Categories } & \multirow{2}{*}{$\begin{array}{l}\text { About how much do you } \\
\text { weigh without shoes? }\end{array}$} & \multicolumn{3}{|c|}{ BMI calculated using weight and height variables } \\
\hline & & ${ }_{-}=$weight in pounds & $\begin{array}{l}\text { BMI calculated using imperial scale: } \\
\text { (weight } X 703 \text { )/ height in inches }{ }^{2}\end{array}$ & $\mathrm{BMI}<25$ \\
\hline & \multirow{3}{*}{$\begin{array}{l}\text { About how tall are you } \\
\text { without shoes? }\end{array}$} & \multirow{2}{*}{\multicolumn{2}{|c|}{${ }_{-}^{\prime}{ }_{-}=$height in feet / inches }} & BMI 25-<30 \\
\hline & & & & $\overline{\mathrm{BMI}}>=30$ \\
\hline & & $\begin{array}{l}\text { Don't know/Not sure, Refused, Not } \\
\text { asked or Missing }\end{array}$ & $\begin{array}{l}\text { Don't know/Not sure, } \\
\text { Refused, Not asked or Missing }\end{array}$ & Missing \\
\hline Physical Activity & $\begin{array}{l}\text { Now, thinking about the } \\
\text { moderate activities you do } \\
\text { in a usual week, do you do } \\
\text { moderate activities for at } \\
\text { least } 10 \text { minutes at a time, } \\
\text { such as brisk walking, } \\
\text { bicycling, vacuuming, } \\
\text { gardening, or anything else } \\
\text { that causes some increase in } \\
\text { breathing or heart rate? }\end{array}$ & $\begin{array}{l}\text { Calculated variable for adults that } \\
\text { have reported participating in either } \\
\text { moderate physical activity defined } \\
\text { as } 30 \text { or more minutes per day for } \\
5 \text { or more days per week, or } \\
\text { vigorous activity for } 20 \text { or more } \\
\text { minutes per day on } 3 \text { or more days. }\end{array}$ & $\begin{array}{l}\text { Respondents who reported doing } \\
\text { enough moderate or vigorous } \\
\text { physical activity to meet the } \\
\text { recommendations }\end{array}$ & $\begin{array}{l}\text { Getting at least moderate } \\
\text { physical activity }\end{array}$ \\
\hline
\end{tabular}


Table 1 Original Survey Question and Response Categories with Re-Coded Response Categories 2009 BRFSS Data (Continued)

\begin{tabular}{|c|c|c|c|c|}
\hline & $\begin{array}{l}\text { How many days per week } \\
\text { do you do these moderate } \\
\text { activities for at least } 10 \\
\text { minutes at a time? }\end{array}$ & & & \\
\hline & $\begin{array}{l}\text { On days when you do } \\
\text { moderate activities for at } \\
\text { least } 10 \text { minutes at a time, } \\
\text { how much total time per } \\
\text { day do you spend doing } \\
\text { these activities? }\end{array}$ & & $\begin{array}{l}\text { Respondents who reported doing } \\
\text { insufficient moderate or vigorous } \\
\text { physical activity to meet } \\
\text { recommendations, or respondents } \\
\text { that reported doing no moderate } \\
\text { or vigorous physical activity }\end{array}$ & Inactive \\
\hline & $\begin{array}{l}\text { Now, thinking about the } \\
\text { vigorous activities you do } \\
\text { in a usual week, do you do } \\
\text { vigorous activities for at } \\
\text { least } 10 \text { minutes at a time, } \\
\text { such as running, aerobics, } \\
\text { heavy yard work, or } \\
\text { anything else that causes } \\
\text { large increases in breathing } \\
\text { or heart rate? }\end{array}$ & & $\begin{array}{l}\text { Respondents who reported they } \\
\text { didn't know whether they did } \\
\text { moderate or vigorous physical } \\
\text { activity or didn't know how many } \\
\text { days or didn't know how much } \\
\text { time they did the activity, those } \\
\text { who refused to answer, and those } \\
\text { with missing responses }\end{array}$ & Missing \\
\hline & $\begin{array}{l}\text { How many days per week } \\
\text { do you do these vigorous } \\
\text { activities for at least } 10 \\
\text { minutes at a time? }\end{array}$ & & & \\
\hline & $\begin{array}{l}\text { On days when you do } \\
\text { vigorous activities for at } \\
\text { least } 10 \text { minutes at a time, } \\
\text { how much total time per } \\
\text { day do you spend doing } \\
\text { these activities? }\end{array}$ & & & \\
\hline \multirow[t]{3}{*}{ Have Health Insurance } & \multirow{3}{*}{$\begin{array}{l}\text { Do you have any kind of } \\
\text { health care coverage, } \\
\text { including health insurance, } \\
\text { prepaid plans such as } \\
\text { HMOs, or government } \\
\text { plans such as Medicare? }\end{array}$} & Yes & & Yes \\
\hline & & $\overline{N o}$ & & No \\
\hline & & Don't know/Not Sure, Refused & & Missing \\
\hline \multirow[t]{4}{*}{ Have a Personal Physician } & \multirow{4}{*}{$\begin{array}{l}\text { Do you have one person } \\
\text { you think of as your } \\
\text { personal doctor or health } \\
\text { care provider? (If "No" ask } \\
\text { "Is there more than one or is } \\
\text { there no person who you } \\
\text { think of as your personal } \\
\text { doctor or health care } \\
\text { provider?".) }\end{array}$} & Yes, only one & & \multirow[t]{3}{*}{ Yes } \\
\hline & & More than one & & \\
\hline & & No & & \\
\hline & & Don't know/Not Sure, Refused, Not asked or Missi & sing & Missing \\
\hline \multirow{3}{*}{$\begin{array}{l}\text { Timing of Last Routine } \\
\text { Medical Check-up }\end{array}$} & \multirow{3}{*}{$\begin{array}{l}\text { About how long has it been } \\
\text { since you last visited a } \\
\text { doctor for a routine } \\
\text { checkup? A routine }\end{array}$} & Within past year (anytime less than 12 months ag & go) & Within the Past 12 Months \\
\hline & & Within past 2 years $(1$ year but less than 2 years a & ago) & \multirow[t]{2}{*}{ More than 12 Months Ago } \\
\hline & & Within past 5 years ( 2 years but less than 5 years & s ago) & \\
\hline
\end{tabular}


Table 1 Original Survey Question and Response Categories with Re-Coded Response Categories 2009 BRFSS Data (Continued)

\begin{tabular}{|c|c|c|c|}
\hline & \multirow{3}{*}{$\begin{array}{l}\text { checkup is a general } \\
\text { physical exam, not an exam } \\
\text { for a specific injury, illness, } \\
\text { or condition. }\end{array}$} & \multicolumn{2}{|l|}{5 or more years ago } \\
\hline & & Never & \\
\hline & & Don't know/Not sure or Refused & Missing \\
\hline \multirow{3}{*}{$\begin{array}{l}\text { Deferment of Medical Care } \\
\text { Because of Cost }\end{array}$} & \multirow{3}{*}{$\begin{array}{l}\text { Was there a time in the past } \\
12 \text { months when you } \\
\text { needed to see a doctor but } \\
\text { could not because of cost? }\end{array}$} & Yes & Yes \\
\hline & & No & No \\
\hline & & Don't know/Not sure, Refused & Missing \\
\hline \multirow[t]{6}{*}{ Self-Defined Health Status } & \multirow{6}{*}{$\begin{array}{l}\text { Would you say that in } \\
\text { general your health is: }\end{array}$} & Excellent & \multirow[t]{3}{*}{ Good to Excellent } \\
\hline & & Very good & \\
\hline & & $\overline{\text { Good }}$ & \\
\hline & & Fair & \multirow[t]{2}{*}{ Fair to Poor } \\
\hline & & Poor & \\
\hline & & Don't know/Not Sure, Refused, Not asked or Missing & Missing \\
\hline \multirow[t]{5}{*}{ Residency by Geographic Locale } & \multirow[t]{5}{*}{ Metropolitan Status Code } & In the center city of an MSA & \multirow[t]{3}{*}{ Non-rural } \\
\hline & & Outside the center city of an MSA but inside the county containing the center city & \\
\hline & & Inside a suburban county of the MSA & \\
\hline & & In an MSA that has no center city & \multirow[t]{2}{*}{ Rural } \\
\hline & & Not in an MSA & \\
\hline
\end{tabular}


Level of physical activity was calculated by combining other variables assessing physical activity level by: 1) whether or not a person was getting recommended levels of moderate physical activity, and 2) whether or not a person was getting recommended levels of vigorous physical activity. People who reported getting recommended levels of either moderate or vigorous physical activity were coded as getting at least recommended levels of moderate physical activity. Recommended levels of moderate physical activity were defined as moderateintensity activities such as brisk walking for at least 30 minutes per day, at least five days a week. Respondents getting less than moderate levels of physical activity were coded as inactive.

\section{Analysis}

Bivariate analysis using unadjusted odds ratios and/or contingency table analysis with a chi square test for statistical significance and multivariate logistic regression using weighted data and adjusted odds ratios as the test statistic were performed. The dependent variable for these analyses was rural US adults consuming at least five daily servings of combined fruits and vegetables. Additionally, ArcView version 10.0 (ESRI, Redlands, CA) was used to map the prevalence differences by State between rural and non-rural adults consuming at least five or more daily servings of fruits and/or vegetables. For this calculation and mapping effort the prevalence of rural adults consuming at least five daily servings of fruits and vegetables by state was compared to the prevalence of their non-rural counterparts in the same state. States were color coded on the map to show if the rural in comparison to non-rural adult population of a state had a higher prevalence or a lower/smaller prevalence of consuming at least 5 daily servings of combined fruits and vegetables.

For all statistical analyses, alpha was set at $\mathrm{p}<0.05$. Statistical Package for Social Scientists (SPSS, IBM, Chicago, IL) version 19.0 was used to complete all statistical analyses performed for this study. Human subject approval was sought and received from Essentia Health's IRB as well as the University of Illinois, College of Medicine at Rockford's IRB.

\section{Results}

\section{Descriptive analysis}

For our study, a single year of data for the year 2009 of non-institutionalized US adults (weighted $n=219,479,823$ ) were analyzed. From the 2009 dataset, a weighted 52,259, 789 US adults were identified as consuming at least 5 servings of fruits and vegetables daily of which $8,983,840$ were identified as living in rural locales. Bivariate analysis revealed that in comparison to US non-rural adults US rural adults were less likely to consume five or more servings of fruits and vegetables $(\mathrm{OR}=1.161,95 \% \mathrm{CI} 1.160-1.162)$ (not shown on table). Table 2 displays additional comparative data for US non-rural and rural adults regardless of daily consumption of fruits and vegetables. Most notably higher proportions of rural adults when compared to non-rural ones were: Caucasian, older ( $>65$ years of age), heavier (BMI > 30), less educated (college graduation), poorer (household income $<\$ 35,000$ ), married or living with a partner, and without health insurance. Further, a higher proportion of rural vs. non-rural adults: did not have children living at home, had not had a routine medical check-up in the past 12 months, and self-defined their health as fair to poor rather than good to excellent.

\section{Bivariate analysis}

Table 3 displays the results of a bivariate analysis for US adults consuming at least five servings of fruits and vegetables daily. As measured by either odds ratio or chi square, all of the covariates in this bivariate analysis yielded a statistically significant relationship with the dependent variable of consuming at least five daily servings of fruits and vegetables. As a result all of the covariates were entered into the multivariate logistic regression model.

\section{Logistic regression analysis}

Table 4 displays the results of the multivariate analysis preformed. Consumption of at least five daily servings of fruits and vegetables was the dependent variable for the model that included only rural adults. The logistic regression analysis revealed that rural adults whose daily consumption of fruits and vegetables included at least five servings were more likely to be: female rather than male; African American, Hispanic or multiracial/other rather than Caucasian; married or living with a partner rather than single; living in a household without children; living in a household whose annual income is at least $\$ 35,000$ compared to an income than less than $\$ 35,000$; and getting at least moderate physical activity rather than being inactive. Rural adults consuming five or more servings of vegetables daily were also more likely to have: a BMI of $<25$ or a BMI of 25 to $<30$ rather than $>30$; have a personal physician; have had a routine medical exam in the past 12 months; and selfdefine their health as good to excellent rather than fair to poor. Rural adults consuming at least five daily servings of fruits and vegetables were also more likely to have deferred medical care because of cost.

Rural adults consuming at least five daily servings of fruits and vegetables were approximately 33\% less likely to be younger (18-34 years or 35-64 years) than older (65 or older). They also were $35.3 \%$ to $47.3 \%$ less likely of being educated beyond high school (have less than a high school education or being a high school graduate) than being a college graduate. 


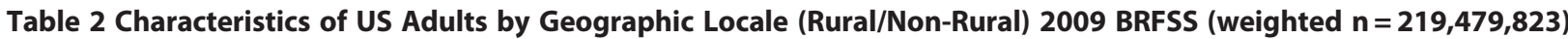

\begin{tabular}{|c|c|c|c|}
\hline Variables and Factors & & $\begin{array}{l}\text { \% Rural* } \\
\text { (weighted } \\
n=42,365,517 \text { ) }\end{array}$ & $\begin{array}{l}\text { \% Non-rural* } \\
\text { (weighted } \\
n=177,114,306 \text { ) }\end{array}$ \\
\hline \multirow[t]{2}{*}{ Fruit and Vegetable Consumption } & $<5$ Servings Daily & 78.8 & 75.6 \\
\hline & At Least 5 Servings Daily & 21.2 & 24.4 \\
\hline \multirow[t]{2}{*}{ Sex } & Male & 48.2 & 48.8 \\
\hline & Female & 51.8 & 51.2 \\
\hline \multirow[t]{4}{*}{ Race And Ethnicity } & Caucasian & 81.3 & 65.6 \\
\hline & African American & 6.2 & 10.9 \\
\hline & Hispanic & 6.6 & 15.2 \\
\hline & Other & 5.8 & 8.2 \\
\hline \multirow[t]{3}{*}{ Age Ranges } & 18-34 Years & 28.4 & 30.4 \\
\hline & 35-64 Years & 51.8 & 53.0 \\
\hline & $>=65$ Years & 19.8 & 16.6 \\
\hline \multirow[t]{3}{*}{ Education } & $<$ High School & 11.8 & 10.4 \\
\hline & Completed High School & 63.5 & 52.7 \\
\hline & College Graduate & 24.6 & 36.9 \\
\hline \multirow[t]{2}{*}{ Marital Status } & Married Or Living With Partner & 66.4 & 63.9 \\
\hline & Unmarried/Not Living With A Partner & 33.6 & 36.1 \\
\hline \multirow[t]{2}{*}{ Children In Household } & No Children In Household & 60.0 & 56.0 \\
\hline & At Least 1 Child In Household & 40.0 & 44.0 \\
\hline \multirow[t]{2}{*}{ Household Income } & $<\$ 35,000$ & 43.6 & 35.1 \\
\hline & $>=\$ 35,000$ & 56.4 & 64.9 \\
\hline \multirow[t]{3}{*}{ BMI Categories } & $\mathrm{BMI}<25$ & 32.8 & 37.2 \\
\hline & BMI $25-<30$ & 36.6 & 36.2 \\
\hline & $\mathrm{BMI}>=30$ & 30.6 & 26.6 \\
\hline \multirow[t]{2}{*}{ Physical Activity } & Getting At Least Moderate Physical Activity & 48.9 & 49.7 \\
\hline & Inactive & 51.1 & 50.3 \\
\hline \multirow[t]{2}{*}{ Have Health Insurance } & Yes & 83.0 & 85.0 \\
\hline & No & 17.0 & 15.0 \\
\hline \multirow[t]{2}{*}{ Have A Personal Physician } & Yes & 81.9 & 80.5 \\
\hline & No & 18.1 & 19.5 \\
\hline \multirow[t]{2}{*}{ Timing Of Last Routine Medical Checkup } & Within Last 12 Months & 65.8 & 68.2 \\
\hline & Longer Than 12 Months Ago & 34.2 & 31.8 \\
\hline \multirow[t]{2}{*}{ Deferment Of Medical Care Because Of Cost } & Deferred Medical Care Because Of Cost & 15.5 & 14.7 \\
\hline & Did Not Defer Medical Care Because Of Cost & 84.5 & 85.3 \\
\hline \multirow[t]{2}{*}{ Self-Defined Health Status } & Good To Excellent & 81.7 & 84.7 \\
\hline & Fair To Poor & 18.3 & 15.3 \\
\hline
\end{tabular}

*All cell percentages by row significantly different by $z$-test measure $p<.05$.

\section{Geographic analysis}

Table 5 displays prevalence of rural and non-rural adults consuming five or more daily servings of fruits and vegetables by State. Weighted data were used to calculate the prevalences using BRFSS. Also displayed in Table 5 are the standardized percent differences between the prevalences of rural and non-rural adults consuming five or more daily servings of fruits and vegetables by state. The state prevalences for rural adults ranged from a low of $13.88 \%$ in Oklahoma to a high of $28.74 \%$ in Vermont.
For non-rural adults the prevalences ranged from a low of $14.44 \%$ in Oklahoma to a high of $28.27 \%$ in Maine.

The differences in prevalences of fruit and vegetable consumption are presented in Figure 1 with states color coded as having either a higher prevalence (light shade) or a lower prevalence (dark shade) of fruit and vegetable consumption for rural adults in comparison to non-rural adults. Thirty-seven states had lower a prevalence of rural adults consuming at least five daily servings of fruits and vegetables and 11 States a higher prevalence of 
Table 3 Bivariate Predictor Variables for US Rural Adults Consuming at Least Five Fruit and Vegetable Servings Daily 2009 BRFSS

\begin{tabular}{|c|c|c|c|}
\hline \multicolumn{3}{|c|}{ Covariates and Factors } & Unadjusted Odds Ratio $(95 \% \mathrm{Cl})$ \\
\hline \multicolumn{3}{|c|}{ Gender (Male vs. Female) } & $.964(.963, .965)$ \\
\hline \multicolumn{3}{|c|}{ Children in Household (No Children In Household vs. At Least 1 Child In Household) } & $1.141(1.139,1.142)$ \\
\hline \multicolumn{3}{|c|}{ Marital Status (Married Or Living With Partner vs. Unmarried/ Not Living With A Partner) } & $1.130(1.128,1.131)$ \\
\hline \multicolumn{3}{|c|}{ Household Income $(<\$ 35,000$ vs. $\geq \$ 35,000)$} & $1.297(1.295,1.299)$ \\
\hline \multicolumn{3}{|c|}{ Health Status (Good to Excellent vs. Fair to Poor) } & $.869(.868, .871)$ \\
\hline \multicolumn{3}{|c|}{ Have Health Insurance (Yes vs. No) } & $.891(.890, .893)$ \\
\hline \multicolumn{3}{|c|}{ Health Care Provider (Have HCP vs. Do Not Have HCP) } & $1.084(1.082,1.086)$ \\
\hline \multicolumn{3}{|c|}{ Medical Care Deferment (Deferred Care Because of Cost vs. Did Not Defer Care) } & $1.059(1.057,1.060)$ \\
\hline \multicolumn{3}{|c|}{ Routine Check-Up (Within Past 12 Months vs. Longer Than 12 Months Ago) } & $.903(.902, .904)$ \\
\hline \multicolumn{3}{|c|}{ Physical Activity (Getting At Least Moderate Physical Activity vs. Inactive) } & $.998(.997, .999)$ \\
\hline \multicolumn{4}{|c|}{ Contingency Table Percentages* } \\
\hline \multicolumn{2}{|c|}{ Covariate and Factors } & Rural** & Non-Rural*** \\
\hline \multirow[t]{4}{*}{ Race/Ethnicity } & Caucasian & $81.3 \%$ & $67.3 \%$ \\
\hline & African American & $5.3 \%$ & $10.3 \%$ \\
\hline & Hispanic & $6.9 \%$ & $13.3 \%$ \\
\hline & Other/Multiracial & $6.6 \%$ & $9.1 \%$ \\
\hline \multirow[t]{3}{*}{ Age Ranges } & 18-34 Years & $26.9 \%$ & $28.3 \%$ \\
\hline & 35-64 Years & $49.4 \%$ & $52.7 \%$ \\
\hline & $>=65$ Years & $23.7 \%$ & $19.0 \%$ \\
\hline \multirow[t]{3}{*}{ Education } & $<$ High School & $8.6 \%$ & $8.3 \%$ \\
\hline & Completed High School & $58.2 \%$ & $47.0 \%$ \\
\hline & College Graduate & $33.3 \%$ & $44.7 \%$ \\
\hline \multirow[t]{3}{*}{ BMI Categories } & $\mathrm{BMl}<25$ & $36.8 \%$ & $42.0 \%$ \\
\hline & BMI 25- <30 & $35.9 \%$ & $35.0 \%$ \\
\hline & $\mathrm{BMI}>=30$ & $27.3 \%$ & $23.0 \%$ \\
\hline
\end{tabular}

** $8,983,840$.

*** $43,275,949$

* In all instances column proportions differ significantly from each other by chi-square test at the .05 level.

rural adults consuming at least five daily servings of fruits and vegetables. In two States (New Jersey and Rhode Island) no data on the fruit and vegetable consumption of rural adults were available.

Of the 11 states with a higher prevalence of rural adults consuming at least five daily servings of fruits and vegetables when compared to the non-rural adult population, only one State, Hawaii, was ranked in the top 10 states for fruit and vegetable production. An additional state, Arizona, ranked in the top 20 of fruit and vegetable producing States.

\section{Discussion}

Chronic disease accounts for about $75 \%$ of the health care costs in the United Sates and several studies document the benefits of a healthy diet for weight control, and for illnesses such as diabetes, cardiovascular disease and certain types of cancer [3-6,47]. Consuming at least five daily servings of fruits and vegetables are considered an essential part of an overall healthy balanced diet [2].
Our study found that less than 1 in 4 rural US adults consumed five or more servings of fruits and vegetables, a result similar to previous research [48], and a proportion that falls dramatically short of the targets set by HP 2010. Our results also revealed that compared to nonrural adults, a smaller proportion of rural adults reported consuming five servings of combined fruits and vegetables. The findings reported here underscore the continued need for developing targeted interventions that effectively result in healthier dietary choices while addressing possible issues of the availability and accessibility of healthy foods such as fresh fruits and vegetables.

While it may be ironic that rural adults, who live where fruits and vegetables grow, were less likely to consume at least five daily servings it is not necessarily unexpected [48-55]. The importance of community environment as a contributor for individuals adopting a healthy lifestyle, including the availability of low cost health food choices, is increasingly being recognized [50]. Although rural communities produce fruits and vegetables, they typically have 
Table 4 Characteristics of US Rural Adults Consuming at Least Five Daily Fruit and Vegetable Servings 2009 BRFSS

\begin{tabular}{|c|c|c|}
\hline \multicolumn{2}{|l|}{ Predictor Variables and Factors } & \multirow{2}{*}{$\begin{array}{l}\text { Rural Adults Adjusted Odds Ratio }(95 \% \mathrm{Cl}) \\
-^{*}\end{array}$} \\
\hline Sex & Male & \\
\hline & Female & $1.666(1.663,1.669)$ \\
\hline \multirow[t]{4}{*}{ Race And Ethnicity } & Caucasian & $-^{*}$ \\
\hline & African American & $1.127(1.123,1.131)$ \\
\hline & Hispanic & $1.474(1.469,1.479)$ \\
\hline & Other & $1.251(1.246,1.255)$ \\
\hline \multirow[t]{3}{*}{ Age Ranges } & 18-34 Years & $.673(.671, .675)$ \\
\hline & 35-64 Years & $.675(.673, .676)$ \\
\hline & $>=65$ Years & $-^{*}$ \\
\hline \multirow[t]{3}{*}{ Education } & $<$ High School & $.527(.525, .529)$ \\
\hline & Completed High School & $.647(.646, .648)$ \\
\hline & College Graduate & $-^{*}$ \\
\hline \multirow[t]{2}{*}{ Marital Status } & Married Or Living With Partner & $1.071(1.069,1.073)$ \\
\hline & Unmarried /Not Living With A Partner & $-{ }^{*}$ \\
\hline \multirow[t]{2}{*}{ Children In Household } & No Children In Household & $1.052(1.050,1.054)$ \\
\hline & At Least 1 Child In Household & $-{ }^{*}$ \\
\hline \multirow[t]{2}{*}{ Household Income } & $<\$ 35,000$ & $-{ }^{*}$ \\
\hline & $>=\$ 35,000$ & $1.111(1.108,1.113)$ \\
\hline \multirow[t]{3}{*}{ BMI Categories } & $\mathrm{BMI}<25$ & $1.126(1.124,1.129)$ \\
\hline & BMI $25-<30$ & $1.066(1.064,1.068)$ \\
\hline & $\mathrm{BMI}>=30$ & $--^{*}$ \\
\hline \multirow[t]{2}{*}{ Physical Activity } & Getting At Least Moderate Physical Activity & $1.881(1.878,1.885)$ \\
\hline & Inactive & $--^{*}$ \\
\hline \multirow[t]{2}{*}{ Have Health Insurance } & Yes & $.962(.959, .964)$ \\
\hline & No & $--^{*}$ \\
\hline \multirow[t]{2}{*}{ Have A Personal Physician } & Yes & $1.045(1.042,1.047)$ \\
\hline & No & $-^{*}$ \\
\hline \multirow[t]{2}{*}{ Timing Of Last Routine Medical Checkup } & Within Last 12 Months & $1.224(1.222,1.226)$ \\
\hline & Longer Than 12 Months Ago & $-{ }^{*}$ \\
\hline \multirow[t]{2}{*}{ Deferment Of Medical Care Because Of Cost } & Deferred Medical Care Because Of Cost & $-{ }^{*}$ \\
\hline & Did Not Defer Medical Care Because Of Cost & $.897(.895, .899)$ \\
\hline \multirow[t]{2}{*}{ Self-Defined Health Status } & Good To Excellent & $1.148(1.145,1.151)$ \\
\hline & Fair To Poor & $-{ }^{*}$ \\
\hline
\end{tabular}

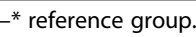

fewer stores that offer a wide selection of healthy lowercost food than non-rural communities [49] and rural residents are more likely to live in a food deserts [56,57]. Since approximately $20 \%$ of the US population lives in rural settings [51] strategies aimed at improving access to healthy foods for rural residents could yield significant health benefits. Furthermore, an additional related issue is the ability and/or willingness of rural residents to travel greater distances to food stores where a greater availability of and choices for fruits and vegetables might be found [31].

In addition to environmental access issues, rural residents are typically poorer than their non-rural counterparts and affordability is likely an important contributing factor to fewer rural residents consuming greater amounts of fruits and vegetables. Our results indicate that a higher proportion of rural residents earning less than $\$ 35,000$ did not consume at least five servings of fruits and vegetables when compared to their non-rural counterparts. Food costs correlate to store type and food tends to be less expensive in larger supermarkets than smaller markets or convenience stores. These higher priced food outlets may be the only local and convenient food source for some rural communities. In addition to a convenience factor, transportation costs may be a barrier to purchasing less expensive healthier food that might be available in a nearby community. 
Table 5 Prevalence of Rural and Non-Rural Adults Consuming Five or More Daily Servings of Fruits and Vegetables 2009 BRFSS Data and 2007 USDA Census Data

\begin{tabular}{|c|c|c|c|c|}
\hline State & $\begin{array}{l}\text { Prevalence } \\
\text { Rural Adults }\end{array}$ & $\begin{array}{l}\text { Prevalence } \\
\text { Non-Rural Adults }\end{array}$ & $\begin{array}{l}\% \text { Difference Between } \\
\text { Rural and Non-Rural Adults }\end{array}$ & $\begin{array}{l}\text { State National Ranking for } \\
\text { Fruit and Vegetable Production* }\end{array}$ \\
\hline Alabama & 17.01 & 20.63 & -21.27 & 17 \\
\hline Alaska & 19.79 & 23.76 & -20.04 & 48 \\
\hline Arizona & 25.39 & 23.13 & 8.90 & 12 \\
\hline Arkansas & 19.01 & 19.74 & -3.87 & 35 \\
\hline California & 22.90 & 24.28 & -6.01 & 1 \\
\hline Colorado & 21.84 & 22.58 & -3.37 & 26 \\
\hline Connecticut & 25.76 & 27.57 & -7.00 & 37 \\
\hline Delaware & 23.45 & 22.75 & 2.96 & 46 \\
\hline Florida & 21.64 & 23.32 & -7.77 & 11 \\
\hline Georgia & 21.94 & 23.58 & -7.50 & 19 \\
\hline Hawaii & 25.79 & 21.40 & 17.05 & 7 \\
\hline Idaho & 21.55 & 25.03 & -16.19 & 34 \\
\hline Illinois & 22.63 & 21.65 & 4.34 & 24 \\
\hline Indiana & 17.17 & 20.34 & -18.42 & 25 \\
\hline lowa & 17.82 & 17.96 & -0.78 & 29 \\
\hline Kansas & 17.24 & 18.48 & -7.20 & 41 \\
\hline Kentucky & 17.30 & 21.96 & -26.91 & 14 \\
\hline Louisiana & 14.48 & 17.25 & -19.16 & 38 \\
\hline Maine & 25.93 & 28.27 & -9.04 & 33 \\
\hline Maryland & 21.24 & 26.99 & -27.05 & 32 \\
\hline Massachusetts & 19.66 & 24.27 & -23.47 & 27 \\
\hline Michigan & 21.39 & 22.05 & -3.06 & 5 \\
\hline Minnesota & 19.53 & 22.70 & -16.25 & 22 \\
\hline Mississippi & 14.26 & 19.02 & -33.36 & 28 \\
\hline Missouri & 18.14 & 18.80 & -3.64 & 23 \\
\hline Montana & 24.35 & 25.88 & -6.28 & 40 \\
\hline Nebraska & 21.23 & 19.45 & 8.35 & 43 \\
\hline Nevada & 23.19 & 22.48 & 3.03 & 49 \\
\hline New Hampshire & 28.45 & 24.71 & 13.17 & 42 \\
\hline New Jersey & N/A & 24.83 & $\mathrm{~N} / \mathrm{A}$ & 20 \\
\hline New Mexico & 21.34 & 22.59 & -5.86 & 15 \\
\hline New York & 24.50 & 25.65 & -4.69 & 4 \\
\hline North Carolina & 17.34 & 21.04 & -21.37 & 6 \\
\hline North Dakota & 21.75 & 21.68 & 0.30 & 47 \\
\hline Ohio & 18.26 & 20.94 & -14.67 & 9 \\
\hline Oklahoma & 13.88 & 14.44 & -4.07 & 31 \\
\hline Oregon & 23.62 & 25.41 & -7.59 & 8 \\
\hline Pennsylvania & 20.34 & 24.01 & -18.04 & 3 \\
\hline Rhode Island & N/A & 25.53 & $\mathrm{~N} / \mathrm{A}$ & 44 \\
\hline South Carolina & 15.33 & 17.31 & -12.88 & 21 \\
\hline South Dakota & 15.71 & 14.29 & 9.04 & 45 \\
\hline Tennessee & 19.73 & 23.26 & -17.90 & 18 \\
\hline Texas & 22.70 & 22.75 & -0.22 & 10 \\
\hline Utah & 19.10 & 23.25 & -21.73 & 30 \\
\hline Vermont & 28.74 & 27.81 & 3.26 & 39 \\
\hline Virginia & 22.60 & 26.89 & -19.00 & 16 \\
\hline
\end{tabular}


Table 5 Prevalence of Rural and Non-Rural Adults Consuming Five or More Daily Servings of Fruits and Vegetables 2009 BRFSS Data and 2007 USDA Census Data (Continued)

\begin{tabular}{lllll}
\hline Washington & 22.60 & 24.90 & -10.17 & 2 \\
\hline West Virginia & 15.90 & 16.18 & -1.81 & 36 \\
\hline Wisconsin & 20.04 & 21.95 & -9.53 & 13 \\
\hline Wyoming & 23.14 & 21.25 & 8.20 & 50 \\
\hline U.S. & 20.38 & 23.07 & -13.19 &
\end{tabular}

* USDA Census 2007 Data on Number of Farms and Acreage Dedicated to Fruit and Vegetable Production by State were used to compute ranking [46].

Our findings also reveal several differences in the consumption of fruits and vegetables by characteristics such as gender, age, education, race/ethnicity, physical activity and reported health status. Similar to other studies [2229], this study found that in rural populations women and those with more education were more likely to consume five or more daily servings of fruits and vegetables. Likewise rural adults over age 65 were more likely to eat at least five servings of fruits and vegetables daily. Data regarding race and ethnicity from previous studies are mixed. In some studies, Caucasians consumed more fruits and vegetables than African Americans while other studies using national data demonstrated the converse [52-55]. Our study found that Caucasians were less likely to consume five servings of fruits and vegetables and that the difference was greater for Caucasians living in rural settings, even though they tended to be better educated and have higher income levels than rural non-Caucasians (combined African Americans, Hispanics, other/Multiracial). The reasons for this difference are not clear and further study to confirm this finding and to understand the reasons why may be helpful in tailoring interventions to improve dietary choices among rural residents.

Those rural residents engaging in at least moderate physical activity and with a lower BMI were also more likely to consume five servings of fruits and vegetables. While physical activity and weight do not directly affect diet choices, our findings add to the body of knowledge that unhealthy lifestyles choices tend to coexist or cluster among individuals [52] just as healthy lifestyle choices do.

Finally, of interest is the distribution of fruit and vegetable consumption by rural and non-rural adults by state. This distribution indicated that in only 11 states did rural adults have a higher prevalence of consuming five or more daily servings of fruits and vegetables than nonrural adults. The reason for this prevalence difference is unclear especially since of those 11 states only one, Hawaii, ranked as a top ten US State for fruit and vegetable production. This finding does suggest the need for

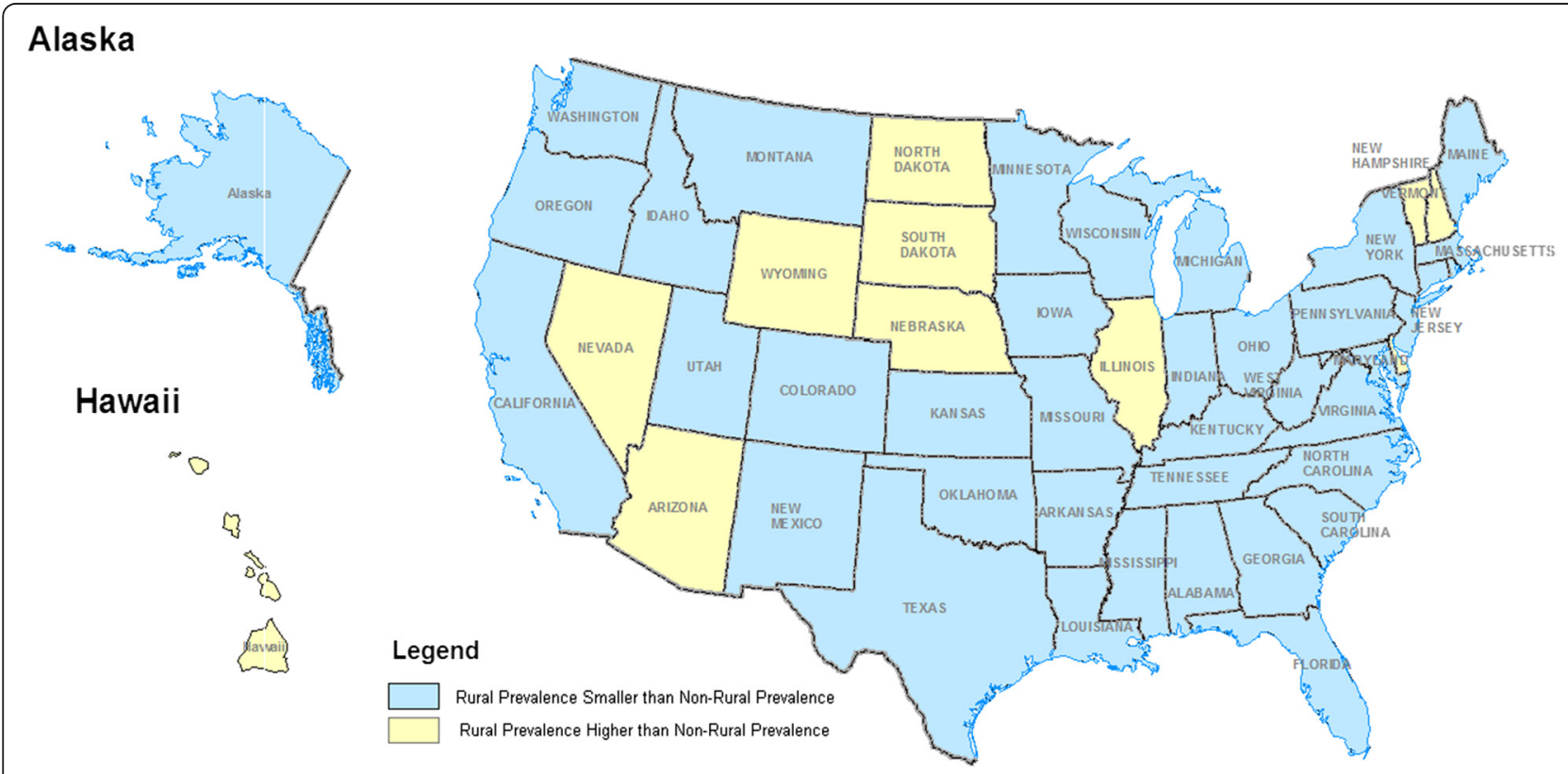

Figure 1 Prevalence of Rural US Adults Consuming at Least Five Daily Servings of Fruits and Vegetables Compared to Non-Rural Adults 2009 BRFSS Data. 
further investigation-specifically to answer the question, are there differences between the rural populations in the states where there is a high prevalence of rural adults who are consuming at least five daily servings of fruits and vegetables and those states where such is not occurring? This might provide insight into the role that community environment plays in diets and for what strategies for improving diets might be best suited to a specific rural settings. Also issues such as climate might be more important for rural residents who may be more likely to grow their own food (e.g., vegetables) and could account for some differences among states.

\section{Limitations}

Several potential limitations to this study should be noted. First, the survey is based on telephone derived data and may be skewed because those who could not be reached by phone could not participate in the survey. For example, persons of lower socioeconomic status may have been excluded because of poorer phone access. However, the fact that the vast majority of US residents live in households with telephones minimizes this bias. Furthermore, US cell phone numbers are now included in the pool of phones contacted for the survey. In addition, study strength is the use of a large multi-state database that includes a robust sample of rural residents weighted to reflect the demographics of rural and non-rural US populations.

A second limitation is that the survey used close-ended questions, which limit a responder's options to fully explain response choices. However, while a different question format may have yielded different results, the survey questions were worded such that the answer choices covered a wide range of response possibilities. A third and related limitation is that the answers are self-reported, which introduces the possibility of recall bias on the part of the survey participants.

Fourthly, the question asking respondents about the number of servings of vegetables is somewhat ambiguous and may have led to an under-reporting of the number of servings of vegetables consumed. For instance no refined measure of consumption was included hence eating vegetables at both lunch and dinner may in actuality constitute more than two servings depending upon the amount of vegetables consumed. Furthermore, the questions did not specifically address vegetables in foods such as stews or soups. However, there is no reason to suspect that there would be reporting differences between rural and non-rural populations suggesting the data can yield meaningful comparisons.

A fifth potential bias resulted from the languages of the survey - English and Spanish. Individuals who did not speak English or Spanish were excluded from this survey. Not all US residents speak the two languages of this survey as a result those adults from other cultures who do not speak either English or Spanish and who have vegetable rich (e.g., Chinese) or fruit and vegetable rich (e.g., Mediterranean) diets may have been excluded and as a result the aggregated data may not be representative of actual consumption by all adults who are residing in the United States.

Finally, in the US, no standard definition exists for rural. In the BRFSS data used in this study, MSA was the only possible definition for rural. The main weakness of the MSA definition is that it does not differentiate well between nonmetropolitan or rural counties. The strengths, however, of the MSA definition are that it is stable over time and it is familiar to policy makers.

\section{Conclusion}

In conclusion, most Americans do not eat the recommended number of servings of fruits and vegetables. However, rural residents appear at greater risk for not making healthy dietary choices. Successfully improving the dietary patterns of Americans will need to incorporate the environmental context in which people live. The enhanced understanding of fruit and vegetable consumption provided from the research reported on here should prove useful to those seeking to lessen the disparity or inequity between rural and non-rural adults in regard to adequate fruit and vegetable consumption. Our findings should be helpful for public health practitioners interested in developing population-level prevention-focused interventions aimed at improving the diets and health of rural Americans and in understanding the importance place plays in the creation of health inequities and the need for developing targeted public health interventions.

\section{Competing interests}

The authors declare that they have no competing interests.

\section{Acknowledgements}

No acknowledgements. There was no external funding for this research study.

\section{Author details}

${ }^{1}$ Essentia Institute of Rural Health, Division of Research, 502 East 2nd Street, Duluth, MN55805, USA. ${ }^{2}$ Department of Community and Family Medicine, University of Illinois-Chicago College of Medicine at Rockford, 1601 Parkview Avenue, Rockford, IL61107, USA.

\section{Authors' contributions}

MNL, LFC, MSL all made substantial contributions to conception and design of the manuscript. MNL was responsible for the acquisition of the data used and the analysis of data. MNL, LFC, MSL were equally involved in interpreting the data, drafting the manuscript and revising it critically for important intellectual content. MNL, LFC, MSL have given final approval of the version to be published. All authors read and approved the final manuscript.

Funding disclosure

We have no funding to disclose. This research was conducted without funding.

Received: 19 September 2011 Accepted: 10 April 2012

Published: 10 April 2012 


\section{References}

1. U.S. Department of Health and Human Services, Office of Disease Prevention and Health Promotion: Healthy People 2020. http://www.healthypeople. gov/2020

2. U.S. Department of AgricultureU.S. Department of Health and Human Services2010Dietary Guidelines for Americans, 20107U.S. Government Printing OfficeWashington, DCU.S. Department of Agriculture, U.S. Department of Health and Human Services: Dietary Guidelines for Americans, 2010. 7th edition. Washington, DC: U.S. Government Printing Office; 2010.

3. Carter P, Gray LJ, Troughton J, Khunti K, Davies MJ: Fruit and vegetable intake and incidence of type 2 diabetes mellitus: systematic review and meta-analysis. BMJ 2010, 341:c4229.

4. Aatola H, Koivistoinen T, Hutri-Kähönen N, Juonala M, Mikkilä V, Lehtimäki T, Viikari JS, Raitakari OT, Kähönen M: Lifetime fruit and vegetable consumption and arterial pulse wave velocity in adulthood: the cardiovascular risk in young Finns study. Circulation 2010, 122:2521-2528.

5. Dauchet L, Amouyel P, Hercberg S, Dallongeville J: Fruit and vegetable consumption and risk of coronary heart disease: a meta-analysis of cohort studies. J Nutr 2006, 136:2588-2593.

6. He FJ, Nowson CA, MacGregor GA: Fruit and vegetable consumption and stroke: meta-analysis of cohort studies. Lancet 2006, 367:320-326.

7. Michimi A, Wimberly MC: Associations of supermarket accessibility with obesity and fruit and vegetable consumption in the conterminous United States. Int I Health Geogr 2010, 9:49.

8. Boggs DA, Palmer JR, Wise LA, Spiegelman D, Stampfer MJ, Adams-Campbell $L L$, Rosenberg $L$ : Fruit and vegetable intake in relation to risk of breast cancer in the black women's health study. Am J Epidemiol 2010, 172:1268-1279.

9. Fernández E, Gallus S, La Vecchia C: Nutrition and cancer risk: an overview. J Br Menopause Soc 2006, 12:139-142.

10. Lee JE, Männistö S, Spiegelman D, Hunter DJ, Bernstein L, van den Brandt PA, Buring JE, Cho E, English DR, Flood A, Freudenheim JL, Giles GG, Giovannucci E, Håkansson N, Horn-Ross PL, Jacobs EJ, Leitzmann MF, Marshall JR, McCullough ML, Miller AB, Rohan TE, Ross JA, Schatzkin A, Schouten LJ, Virtamo J, Wolk A, Zhang SM, Smith-Warner SA: Intakes of fruit, vegetables, and carotenoids and renal cell cancer risk: a pooled analysis of 13 prospective studies. Cancer Epidemiol Biomarkers Prev 2009, 18:1730-1739.

11. Büchner FL, Bueno-de-Mesquita HB, Ros MM, Overvad K, Dahm CC, Hansen L, Tjønneland A, Clavel-Chapelon F, Boutron-Ruault MC, Touillaud M, Kaaks R, Rohrmann S, Boeing H, Nöthlings U, Trichopoulou A, Zylis D, Dilis V, Palli D, Sieri $\mathrm{S}$, Vineis $\mathrm{P}$, Tumino $\mathrm{R}$, Panico $\mathrm{S}$, Peeters $\mathrm{PH}$, van Gils $\mathrm{CH}$, Lund $\mathrm{E}$, Gram IT, Braaten T, Sánchez MJ, Agudo A, Larrañaga N, Ardanaz E, Navarro C, Argüelles MV, Manjer J, Wirfält E, Hallmans G, Rasmuson T, Key TJ, Khaw KT, Wareham N, Slimani N, Vergnaud AC, Xun WW, Kiemeney LA, Riboli E: Variety in fruit and vegetable consumption and the risk of lung cancer in the European prospective investigation into cancer and nutrition. Cancer Epidemiol Biomarkers Prev 2010, 19:2278-2286.

12. Benetou V, Orfanos P, Lagiou P, Trichopoulos D, Boffetta P, Trichopoulou A: Vegetables and fruits in relation to cancer risk: evidence from the Greek EPIC cohort study. Cancer Epidemiol Biomarkers Prev 2008, 17:387-392.

13. McCabe-Sellers BJ, Skipper A, American Dietetic Association: Position of the American Dietetic Association: integration of medical nutrition therapy and pharmacotherapy. J Am Diet Assoc 2010, 110:950-956.

14. Chobanian AV, Bakris GL, Black HR, Cushman WC, Green LA, Izzo JL Jr, Jones DW, Materson BJ, Oparil S, Wright JT Jr, Roccella EJ, National Heart, Lung, and Blood Institute Joint National Committee on Prevention, Detection, Evaluation, and Treatment of High Blood Pressure, National High Blood Pressure Education Program Coordinating Committee: The seventh report of the Joint National Committee on Prevention, Detection, Evaluation, and Treatment of High Blood Pressure: the JNC 7 report. JAMA 2003, 289:2560-2572.

15. Sacks FM, Svetkey LP, Vollmer WM, Appel LJ, Bray GA, Harsha D, Obarzanek E, Conlin PR, Miller ER 3rd, Simons-Morton DG, Karanja N, Lin PH, DASH-Sodium Collaborative Research Group: Effects on blood pressure of reduced dietary sodium and the Dietary Approaches to Stop Hypertension (DASH) diet. DASH-Sodium Collaborative Research Group. N Engl J Med 2001, 344:3-10.

16. Executive summary of the third report of the National Cholesterol Education Program (NCEP) Expert Panel on detection, evaluation, and treatment of high blood cholesterol in adults (Adult Treatment Panel III). JAMA 2001, 285:2486-2497.
17. Hartley D: Rural health disparities, population health, and rural culture. Am J Public Health 2004, 94:1675-1678.

18. Lovasi GS, Hutson MA, Guerra M, Neckerman KM: Built environments and obesity in disadvantaged populations. Epidemiol Rev 2009, 31:7-20.

19. Lutfiyya MN, McCullough JE, Lipsky MS: A population-based study of health services deficits for U.S. adults with asthma. J Asthma 2011, 48:931-944.

20. Braveman P: Health disparities and health equity: concepts and measurement. Annu Rev Public Health 2006, 27:167-194.

21. Phelan JC, Link BG, Tehranifar P: Social conditions as fundamental causes of health inequalities: theory, evidence, and policy implications. $J$ Health Soc Behav 2010, 51:S28-S40.

22. Dubowitz T, Heron M, Bird CE, Lurie N, Finch BK, Basurto-Da'vila R, Hale L, Escarce JJ: Neighborhood socioeconomic status and fruit and vegetable intake among whites, blacks, and Mexican Americans in the United States. Am J Clin Nutr 2008, 87:1883-1891.

23. Devine CM, Wolfe WS, Frongillo EA Jr, Bisogni CA: Life-course events and experiences: association with fruit and vegetable consumption in 3 ethnic groups. J Am Diet Assoc 1999, 99:309-314.

24. Yeh MC, Ickes SB, Lowenstein LM, Shuval K, Ammerman AS, Farris R, Katz DL: Understanding barriers and facilitators of fruit and vegetable consumption among a diverse multi-ethnic population in the USA. Health Promot Int 2008, 23:42-51.

25. Baker AH, Wardle J: Sex differences in fruit and vegetable intake in older adults. Appetite 2003, 40:269-275.

26. Savoca MR, Arcury TA, Leng X, Bell RA, Chen H, Anderson A, Kohrman T, Quandt SA: The diet quality of rural older adults in the South as measured by healthy eating index-2005 varies by ethnicity. J Am Diet Assoc 2009, 109:2063-2067.

27. Eikenberry N, Smith C: Healthful eating: perceptions, motivations, barriers, and promoters in low-income Minnesota communities. J Am Diet Assoc 2004, 104:1158-1161.

28. Sisson A: Fruit and vegetable consumption by low-income Americans. 2002. Nutrition Noteworthy, Department of Biological Chemistry, UCLA, David Geffen School of Medicine, UC Los Angeles. http://escholarship.org/ uc/item/4kc331×6

29. Montez JK, Eschbach K: Country of birth and language are uniquely associated with intakes of fat, fiber, and fruits and vegetables among Mexican-American women in the United States. J Am Diet Assoc 2008, 108:473-480.

30. Hosler AS, Rajulu DT, Fredrick BL, Ronsani AE: Assessing retail fruit and vegetable availability in urban and rural underserved communities. Prev Chronic Dis 2008, 5:A123.

31. Sharkey JR, Johnson CM, Dean WR: Food access and perceptions of the community and household food environment as correlates of fruit and vegetable intake among rural seniors. BMC Geriatr 2010, 10:32.

32. Kanungsukkasem U, Ng N, Van Minh H, Razzaque A, Ashraf A, Juvekar S, Masud Ahmed S, Huu Bich T: Fruit and vegetable consumption in rural adult population in INDEPTH HDSS sites in Asia. Glob Health Action 2009; 2.

33. Berke EM: Geographic Information Systems (GIS): recognizing the importance of place in primary care research and practice. J Am Board Fam Med 2010, 23:9-12.

34. Cummins S, Curtis S, Diez-Roux AV, Macintyre S: Understanding and representing 'place' in health research: a relational approach. Soc Sci Med 2007, 65:1825-1838.

35. Lutfiyya MN, Lipsky MS, Wisdom-Behounek J, Inpanbutr-Martinkus M: Is rural residency a risk factor for overweight and obesity for U.S. children? Obesity (Silver Spring) 2007, 15:2348-2356.

36. Jackson JE, Doescher MP, Jerant AF, Hart LG: A national study of obesity prevalence and trends by type of rural county. $J$ Rural Health 2005, 21:140-148.

37. Schwartz F, Ruhil AV, Denham S, Shubrook J, Simpson C, Boyd SL: High self-reported prevalence of diabetes mellitus, heart disease, and stroke in 11 counties of rural Appalachian Ohio. I Rural Health 2009, 25:226-230.

38. Krishna S, Gillespie KN, McBride TM: Diabetes burden and access to preventive care in the rural United States. J Rural Health 2010, 26:3-11.

39. Mokdad AH, Stroup DF, Giles WH: Behavioral Risk Factor Surveillance Team. Public health surveillance for behavioral risk factors in a changing environment: recommendations from the Behavioral Risk Factor Surveillance Team. MMWR 2003, 52(RR-9):1-12.

40. U.S. Office of Management and Budget. 2010 standards for delineating metropolitan and micropolitan statistical areas; Notice. Federal Register 2010, 75 . 
41. Isserman AM: In the national interest: defining rural and urban correctly in research and public policy. Int Reg Sci Rev 2005, 28:465-499.

42. Hart LG, Larson EH, Lishner DM: Rural definitions for health policy and research. Am J Public Health 2005, 95:1149-1155.

43. Woods M: Rural geography: blurring boundaries and making connections. Prog Hum Geogr 2009, 33:849-858.

44. Hall SA, Kaufman JS, Ricketts TC: Defining urban and rural areas in U.S. epidemiologic studies. J Urban Health 2006, 83:162-175.

45. Hall JN, Moore S, Harper SB, Lynch JW: Global variability in fruit and vegetable consumption. Am J Prev Med 2009, 36:402-409.

46. United States Department of Agriculture: 2007 Census of Agriculture United States Summary and State Data. Geographic Area Series Part 51 2009, 1 .

47. Terry P, Terry JB, Wolk A: Fruit and vegetable consumption in the prevention of cancer: an update. J Intern Med 2001, 250:280-290.

48. Blanck HM, Gillespie C, Kimmons JE, Seymour JD, Serdula MK: Trends in fruit and vegetable consumption among U.S. men and women, 1994-2005. Prev Chronic Dis 2008, 2:A35.

49. Liese $A D$, Weis KE, Pluto $D$, Smith E, Lawson A: Food store types, availability, and cost of foods in a rural environment. J Am Diet Assoc 2007, 107:1916-1923.

50. Glanz K, Sallis JF, Saelens BE, Frank LD: Healthy nutrition environments: concepts and measures. Am J Health Promot 2005, 19:330-333. ii.

51. Central Intelligence Agency World Factbook. 2011. https://www.cia.gov/ library/publications/the-world-factbook/geos/us.html

52. Deshmukh-Taskar P, Nicklas TA, Yang SJ, Berenson GS: Does food group consumption vary by differences in socioeconomic, demographic, and lifestyle factors in young adults? The Bogalusa Heart Study. J Am Diet Assoc 2007, 107:223-234

53. Patterson BH, Harlan LC, Block G, Kahle L: Food choices of whites, blacks, and Hispanics: data from the 1987 National Health Interview Survey. Nutr Cancer 1995, 23:105-119.

54. Gans KM, Burkholder GJ, Risica PM, Lasater TM: Baseline fat-related dietary behaviors of white, Hispanic, and black participants in a cholesterol screening and education project in New England. J Am Diet Assoc 2003, 103:699-706.

55. Champagne CM, Bogle ML, McGee BB, Yadrick K, Allen HR, Kramer TR, Simpson P, Gossett J, Weber J, Lower Mississippi Delta Nutrition Intervention Research Initiative: Dietary intake in the lower Mississippi delta region: results from the foods of our delta study. J Am Diet Assoc 2004, 104: 199-207.

56. Larson NI, Story MT, Nelson MC: Neighborhood environments: disparities in access to healthy foods in the U.S. Am J Prev Med 2009, 36:74-81.

57. Morton LW, Blanchard C: Starved for access: life in rural America's food deserts. Rural Real 2007, 1:1-10.

\section{doi:10.1186/1471-2458-12-280}

Cite this article as: Lutfiyya et al: A cross-sectional study of US rural adults' consumption of fruits and vegetables: do they consume at least five servings daily?. BMC Public Health 2012 12:280.

\section{Submit your next manuscript to BioMed Central and take full advantage of:}

- Convenient online submission

- Thorough peer review

- No space constraints or color figure charges

- Immediate publication on acceptance

- Inclusion in PubMed, CAS, Scopus and Google Scholar

- Research which is freely available for redistribution 